\title{
BIO-CHEMICAL BIOMARKERS IN ALGAE SCENEDESMUS OBLIQUUS EXPOSED TO HEAVY METALS CD, CU AND ZN
}

\author{
Jelan Elsayed \\ Environmental Pollution (Microbiology), Faculty of Fish Resources, Suez University, Egypt. \\ *Corresponding Author E-mail: jelanmofeed@hotmail.com
}

This is an open access article distributed under the Creative Commons Attribution License, which permits unrestricted use, distribution, and reproduction in any medium, provided the original work is properly cited.

\section{ARTICLE DETAILS}

Article history:

Received 12 August 2016

Accepted 12 December 2016

Available online 20 January 2017

\section{ABSTRACT}

Laboratory studies were conducted to determine the effects of different concentrations of $\mathrm{Cu}, \mathrm{Cd}, \mathrm{Zn}$ and mixture (equal concentrations from the three heavy metals) on growth and some oxidative stress (catalase and glutathione resuctase) on Scenedesmus obliquus (microalgae) after exposure to 24, 48, and $96 \mathrm{~h}$. In addition, the uptake of $\mathrm{Cu}, \mathrm{Cd}$ and $\mathrm{Zn}$ were determined in the culture medium after 24, 48 and 96h of exposure. The catalase and glutasthion resuctase enzyme activities were used as biomarkers to evaluate the toxic effects of $\mathrm{Cu}, \mathrm{Cd}, \mathrm{Zn}$ and mixture (equal concentrations from the three heavy metals) on the microalgae. Enzymatic activities were measured in the presence of each compound alone after 24, 48 and $96 \mathrm{~h}$ and also inmixture after the same time of exposure. The results showed that $\mathrm{Cu}, \mathrm{Cd}, \mathrm{Zn}$ and mixture induced antioxidative enzyme activities (CAT and GR) at different concentrations. Catalase activities (CAT) in both heavy metals treatedalgae were significantly increased. Additionally, a decrease in Chl.a, Chl.b and caritenoids was observed in algae after 24, 48 and 96 h of exposure to both $\mathrm{Cu}, \mathrm{Cd}, \mathrm{Zn}$ and mixture (equal concentrations from the three heavy metals).

\section{KEYWORDS}

Biomarkers, Scenedesmus obliquus (microalgae), heavy metals and oxidative stress.

\section{INTRODUCTION}

Heavy metals group is one of the main water pollutants. In aquatic environment, heavy metals present naturally with low concentration, which are not harmful to the environment and trace amounts of some heavy metals, including manganese, copper, iron, cobalt, zinc and molybdenum may play very important roles in both growth and metabolism of the aquatic organisms [1]. The Environmental Protection Agency reported that, heavy metals have major importance in bioavailability studies due to their potential for human exposure and increased health risk [2]. The presence of heavy metals in the aquatic environment in excess reveal the occurrence of additional extra sources. Those sources could be natural "erosion, volcano and deposition" or resulted from anthropogenic activities "domestic sewage, industrial effluent and agricultural run-off" [3]. Many heavy metals are known to reduce growth and interrupt metabolic activities, while, high concentrations have ecotoxicological effects [4,5]. The toxic effects of heavy metals towards aquatic organisms depend not only on their concentrations but also on the forms of their occurrence [6]. So, contamination of the aquatic environment by non-biodegradable heavy metals has been a subject of much concern in the recent years $[7,8]$.

Algae considered as the primary producers and the basis of most aquatic ecosystems, hence, algae have been shown to be good bioindicators to qualitative and quantitative heavy metal contamination, specially, microalgae which are sensitive to any environmental changes $[9,10]$. Both diatoms and green algae are the most universally used microalgae for toxicity tests [7]. Pollution by heavy metals cause disturbance in aquatic ecosystems, which lead to loss of biodiversity as well as increase in bioaccumulation and hence, magnify the toxicants effect in the food chain [11]. These metals may cause toxic effects and teratogenic changes to aquatic organisms and hence the consumers of it. They also remain in the sediments and slowly released into the final receptors. Therefore, because water considered as the basis for all living organisms, protection of aquatic environment is necessary for the entire ecosystem and also in order to reduce the risk on human health [12].

Many organisms, including microalgae utilize Zinc as an essential micronutrient, where it acts as enzyme cofactor; however, higher concentrations are toxic to most aquatic life. Since it decreases cell division, carotenoids, otal chlorophyll, mobility and ATPase activity in microalgae [13]. High human intake of Zn causes violent vomiting, abdominal pain, degenerative changes in the liver and collapse. Copper infrequently found in natural water but mostly increase by anthropogenic polluted water, where it is originating from dumped sewage, industrial effluents, pesticide or seepage [14]. High concentration of $\mathrm{Cu}$ results in headache, cirrhosis, necrosis, gastrointestinal disturbance where it inhibits enzymatic reactions and even liver failure [15]. Cadmium which considered as the most toxic element to human life, causes reduced immunopotency, cardiac enlargement, cause hyperglycaemia, gonadal atrophy, pulmonary emphysema and kidney failure. Meanwhile, poisoning by lead causes abdominal pain, anemia, weight and coordination loss, insomnia, constipation and vomiting $[16,17]$. Natural unpolluted waters can also contain low concentrations of lead in the form of organic lead complexes. High concentrations of lead have serious effects related to the central nervous system. Severe toxicity by lead cause abortions, sterility and neonatal mortality [18]. Generally, heavy metal considered as major environmental pollutants and regarded to be cytotoxic, mutagenic and carcinogenic. The bioaccumulation of metals by bacteria, fungi and algae has been extensively studied in the last years. Of the studied microorganism, algae are gaining attention, because of the fact that, algae are rich source in the aquatic environment, relatively cheap, quick and able to accumulate high metal content. Hence, microalgae have been widely used in biological monitoring and assessment of safe environmental levels of heavy metals.

Hence, in the present study focus on the use of microalgae as bioindicator for heavy metals, by evaluating the toxic effect of different concentration of some heavy metals on growth, photosynthesis, and some physiological activities of the microalgae Scenedesmus obliquus.

\section{MATERIAL AND METHODS}

\subsection{Microalgae culture}

The microalga Scenedesmus obliquus (SAG 276-3a; Gottingen, Germany cultures; formerly S. acutus; was maintained in batch cultures containing $200 \mathrm{~mL}$ of mineral growth medium (pH 6.3; [19,20]. This medium consisted of (in mg L-1): $\mathrm{ZnSO}_{\text {_ }} 7 \mathrm{H} 20$ 0.0063; LiCl 0.0075; KI 0.249; NH4VO3 0.0029; KNO3 1000; NiSO4 _ 7H2O 0.023; $\mathrm{MnCl} 2$ $4 \mathrm{H} 2 \mathrm{O}$ 0.099; $\mathrm{CuSO}_{\text {_ }} 5 \mathrm{H} 2 \mathrm{O}$ 0.0025; $\mathrm{Al} 2(\mathrm{SO} 4) \overline{3}$ _ $14 \mathrm{H} 2 \mathrm{O} 5.88 ; \mathrm{MgSO}_{4}$ 24.4; H3BO2 0.031; KH2PO4 740; KBr 0.237; (NH4)6Mo7026_4H2O - 
0.0018; Na2HPO4_3H2O 260; Fe2(SO4)3 14.4; Tritiplex III EDTA 13.3 CoSO4_6H2O 0.0028.

Aeration to the algal culture must be continuous with filtered air and placed on an orbital shaker $(130 \mathrm{rpm})$ at $2272 \mathrm{1C}$ and under white fluorescent lamps provided continuous illumination of $63 \mu \mathrm{mol}$ PAR/ $\mathrm{m} 2 / \mathrm{s}$ (Sylvania Grolux F 36W). Microalgae suspensions were continuously bubbled. Into $200 \mathrm{~mL}$ of fresh growth medium, $20 \mathrm{~mL}$ of 1-week-old suspension were added every week to made the subcultures.

\subsection{Treatment with heavy metals}

A stock solution of $\mathrm{Cu}, \mathrm{Cd}, \mathrm{Zn}$ and mixture (equal concentrations from the three heavy metals) from (100 mg L-1 of active ingredient) were made to reach final concentrations of $1,5,10,20,50$ and $100 \mathrm{mg} \mathrm{L}-1$. Toxicity was evaluated after 24,48 and 96 hours in well microplates. The microplates were placed on an orbital shaker $(600 \mathrm{rpm})$ at 2272 $1 \mathrm{Co}$ and under continuous light with intensity, $62.75 \mathrm{mmol} \mathrm{PAR} / \mathrm{m} 2 / \mathrm{s}$ for 24,48 and $96 \mathrm{~h}$. After the incubation period, the algae were collected and centrifuged $\left(2300_{-}\right.$g, $\left.20 \mathrm{~min}\right)$.

\subsection{Determination of lethal concentrations}

The tests were conducted to determine the lethal concentrations (LC50) of $\mathrm{Cd}, \mathrm{Cu}$ and $\mathrm{Zn}$ against $\mathrm{S}$. obliquus as described above, a range of different concentrations of $\mathrm{Cd}, \mathrm{Cu}$ and $\mathrm{Zn}(1,5,10,20,50$ and 100 $\mathrm{mg} \mathrm{L}-1$ ), formulations were prepared in $100 \mathrm{~mL}$ of distilled water. The toxicity was evaluated after 24,48 and $96 \mathrm{~h}$ in microplates. Three replicates without $\mathrm{Cd}, \mathrm{Cu}$ or $\mathrm{Zn}$ were used as control. After 24, 48 and $96 \mathrm{~h}$ the LC10, LC25, and LC50 values were determined graphically according to Finney (1971). LC values from three experiments were averaged and mean standard deviations are presented.

\subsection{Growth rate determination}

The growth rate of S. obliquus was determined by counting cell number with Malassey's cell. The cell growth rate was calculated for 24,48 and $96 \mathrm{~h}$ after addition of the heavy metals " $\mathrm{Cu}, \mathrm{Cd}$ and $\mathrm{Zn}$ " with different concentrations $(1,5,10,20,50$ and $100 \mathrm{mgL}-1)$ to the medium.

\subsection{Metal Uptake}

To determination at metal uptake by the algae; the salts of respective metal like cobber sulphate (CuSO4), cadmium chloride ( $\mathrm{CdCl} 2$ ) and Zinc chloride $(\mathrm{ZnCl} 2)$ were dissolved in double distilled water in different concentration like 1, 5, 10, 20, 50 and $100 \mathrm{ppm}$. (Control without metal concentration used). Heavy metals like cadmium (Cd), Zinc $(\mathrm{Zn})$ and cobber $(\mathrm{Cu})$ estimation of samples were done digesting with $\mathrm{HClO} 4$, HNO3 $(1: 4 \mathrm{~V} / \mathrm{V})$ and diluted with double distilled water. The various concentration of metals was measured by using Inductively Couple Plasma spectrometer, Perkin Elmer Corporation (ICP optima 3300RL).

Uptake of heavy metals by isolated microorganism. The isolated microorganism was cultured in YPG broth at $30{ }^{\circ} \mathrm{C}$ for 4 days and was then harvested by centrifugation at $2000 \mathrm{~g}$ for $15 \mathrm{~min}$. Next, $100 \mathrm{mg}$ (dry weight) of harvested cells were suspended in $100 \mathrm{ml}$ of $10 \mathrm{mM}$ Tris$\mathrm{HCl}$ buVer (pH 7.0) containing $1-5 \mathrm{mg}$ of either $\mathrm{Cd} 2+, \mathrm{Zn} 2+$ or $\mathrm{Cu} 2+$, or $2.5 \mathrm{mg}$ each of $\mathrm{Cd} 2++\mathrm{Zn} 2+, \mathrm{Cu} 2++\mathrm{Zn} 2+$, and $\mathrm{Cd} 2++\mathrm{Cu} 2+$. These suspended solutions were shaken at $100 \mathrm{rpm}$ at $30{ }^{\circ} \mathrm{C}$. Residual heavy metals in the upper phase following centrifugation at $2000 \mathrm{~g}$ for $15 \mathrm{~min}$ were quantiWed by atomic absorption spectrophotometry (Shimadzu, Japan).

\subsection{Enzyme assays}

For determination the enzyme activities, algal suspensions were incubated for 24, 48 and $96 \mathrm{~h}$ in $20 \mathrm{~mL}$ of medium supplied with different concentrations of $\mathrm{Cd}, \mathrm{Cu}$ and $\mathrm{Zn}$ under the conditions described above. After 24,48 and $96 \mathrm{~h}$ of exposure, the cultures were collected, and the enzyme extracts were obtained after centrifugation (5 min, $2000 \mathrm{~g}, 8 \mathrm{0C}$ ) of an algal suspension containing $300-420 \mathrm{mg}$ of chlorophyll. The algal pellet was resuspended in $250 \mathrm{~mL}$ of sodium phosphate buffer $(0.1 \mathrm{M}, \mathrm{pH} 7)$ and was ground in a porcelain mortar with some Fontainebleau sand. For 5 min, the extract was washed in $200 \mathrm{~mL}$ of potassium phosphate buffer $(50 \mathrm{mM}, \mathrm{pH}$ 7.5). Enzyme extracts were then collected and centrifuged for $25 \mathrm{~min}$ at $1500 \mathrm{~g}$ (5 1C). Both extracts were centrifuged again for $20 \mathrm{~min}$ at $25,000 \mathrm{~g}(2 \mathrm{OC})$. The protein content was determined according to Bradford (1976).

The catalase (CAT) activity was measured spectrophotometrically by following the consumption of $\mathrm{H} 2 \mathrm{O} 2$ at $240 \mathrm{~nm}$ for 1 min at $251 \mathrm{C}$, in potassium phosphate buffer $(750 \mathrm{~mL}, 50 \mathrm{mM}, \mathrm{pH} 7.5)$ containing the enzyme extract (10 mg protein). An addition of $200 \mathrm{mM}$ _H2O2 (100 $\mathrm{mL}$ ) started the enzymatic reaction [21]. Absorbance at $340 \mathrm{~nm}$ was followed for $4 \mathrm{~min}$ and the activity was expressed as the consumption of micromoles of CDNB per minute and per milligram of protein.

\subsection{Total chlorophyll, chlorophyll a, b and carotenoids.}

After 96 hours of exposure, $4 \mathrm{ml}$ of $100 \%$ acetone was placed into a knownconcentrated cells titer (from each concentration of the three heavy metals) of $1 \mathrm{~mL}$ and homogenized at $1000 \mathrm{rpm}$ for one min. The homogenate was centrifuged at $2500 \mathrm{rpm}$ for $10 \mathrm{~min}$. The supernatant was separated and the absorbance was read at $400-700 \mathrm{~nm}$ on Schimadzu UV-260 spectrophotometer. It was recorded that chlorophyll a showed the maximum absorbance at $662 \mathrm{~nm}$ while chlorophyll b at $646 \mathrm{~nm}$ and the amounts of these pigments were calculated according to the simultaneous equations [22]. Maine while the carotenoids were calculated according to Holm (1954) as follows:

$$
\text { Chl a }=11.75 \text { A662 - 2.350 A646 }
$$

Chl b $=18.61$ A646 - 3.960 A662

Chl. $a+b=17.76$ A646 + 7.34 A662

Car. $=4.69$ A440 -0.267 Chl. $\mathrm{a}+\mathrm{b}$

\subsection{Statistical analysis}

All experiments were performed in four replicates and repeated three times. Data presented in this study are the means standard deviation (SD). Significant differences between controls and contaminated samples were determined by the Mann and Whitney test and Pvalueso 0.05 were considered significant $\left({ }^{*}\right)$. All statistical analyses were performed with Sigma Stat 2.03 (SSCP Inc.) for Windows. The cluster analysis is an explicit way of multivariate analysis identifying similarity and relations between parameters in row data [23]. BrayCurtis dissimilarity index in cluster analysis has been used by the MVSP program (multivariate statistical package).

\section{RESULTS}

\section{$3.1 \%$ Inhibition of growth rate}

The values of LC10 $(99.4 \pm 3.8,120.3 \pm 3.4$ and $75.6 \pm 3.9 \mu \mathrm{g} \mathrm{L}-1$ after $24 \mathrm{~h}$ for $\mathrm{Cu}, \mathrm{Cd}$ and $\mathrm{Zn}$, respectively) are shown in (Table 1). The $\mathrm{S}$. obliquus was then exposed to those sub lethal concentrations and the physiological parameters were measured after 24,48 and $96 \mathrm{~h}$ of exposure.

Inspection of table ( 2 and 3 ) revelled that, the rate of growth inhibition of S. obliquus in different concentration $(5,10,50$ and $100 \mu \mathrm{g} \mathrm{L}-1)$ for the tested heavy metals ( $\mathrm{Cu}, \mathrm{Cd}, \mathrm{Zn}$ and $\mathrm{HM}$ mix.) have more or less the same trend, except with low concentration, especially in case of $\mathrm{Cu}$ and $\mathrm{Zn}$. Where, the low concentration of Zn (5 $\mu \mathrm{g} \mathrm{L-1)}$ enhance the growth rate compared to the control by about $4.1-2.9 \%$, while $\mathrm{Cu}$ support growth within the lowest concentration ( $5 \mu \mathrm{g} \mathrm{Cu} \mathrm{L-1)}$ by $1.3 \%$ after 24 $\mathrm{h}$ and $0.9 \%$ after $48 \mathrm{~h}$. In contrast with that, the same concentration of $\mathrm{Cd}$ shows no effect on the growth rate. On the whole, the inhibition rate of the studied alga was increased with increase of the heavy metals ( $\mathrm{Cu}$, $\mathrm{Cd}, \mathrm{Zn}$ and $\mathrm{HM}$ mix.) concentrations as well as longer exposure period, giving the maximum inhibition within $100 \mu \mathrm{g} \mathrm{L}-1$ (25.4 - 58.9 $\mu \mathrm{g} \mathrm{Cu} \mathrm{L-1}$, 47.8 - $75.8 \mu \mathrm{g}$ Cd L-1, 20.6 - $37.7 \mu \mathrm{g} \mathrm{ZnL-1}$ and 54 -84.3 $\mu \mathrm{g} \mathrm{HM} \mathrm{mix} \mathrm{L-1).}$ Concerning the rate of growth inhibition after exposure for 24-96 $\mathrm{h}$ clarify that, except within the mix., Cd gave the higher inhibition rate within all its concentrations, followed by $\mathrm{Cu}$ and then $\mathrm{Zn}$. It is worth mentioning that, the control reflects no growth inhibition through over the time of experiment.

\subsection{Effects of metals on the photosynthesis}

Compared with the control, the obtained concentration of chlorophyll a, $\mathrm{b}$ and carotenoids show different response to the different concentrations of the three tested heavy metals $(\mathrm{Cu}, \mathrm{Cd}$ and $\mathrm{Zn})$ and $\mathrm{HM}$ mix. A glance on figure (1) reveal that, $\mathrm{Cu}$ enhance both chlorophyll a and $\mathrm{b}$ within the low concentration during the exposure period. Where, Chl. as was $43.8 \mathrm{mg} / \mathrm{g}$ with $1 \mu \mathrm{gL}-1$, while Chl.b reached $26.4 \mathrm{mg} / \mathrm{g}$ within the same concentration. In contrast with high $\mathrm{Cu}$ concentrations which inhibit both of them giving its maximum inhibition $(16.3 \mathrm{mg} / \mathrm{g}$ 
for chl.a and $9.8 \mathrm{mg} / \mathrm{g}$ for chl.b) at $100 \mu \mathrm{gL}-1$. On the other hand, carotenoids maintain gradual decrease with increase of $\mathrm{Cu}$ concentration, where it decreases by $61.7 \%$ within the highest concentration. A more or less the same phenomena recorded in case of zinc, which support the increase in chl.a $(40.2 \mathrm{mg} / \mathrm{g})$ and chl.b $(23.1$ $\mathrm{mg} / \mathrm{g}$ ) only within the lowest concentration ( $5 \mu \mathrm{gL}-1$ ). It is worth mentioning that, caritenoid tended to be unchanged $(14.1 \mathrm{mg} / \mathrm{g})$ within concentrations 10 and $50 \mu \mathrm{g} \mathrm{Zn} \mathrm{L-1.} \mathrm{However,} \mathrm{the} \mathrm{other}$ treatments of Cadmium and the HM mixture inhibit the values of chl.a,b and caritenoid with a marked superiority of the HM mixture inhibition. An overview of the results clarifies that, the highest inhibition percentage always recorded in chl.a.

\subsection{CAT activity}

Anent, CAT activity of Scenedesmus cell in different concentrations of the tested heavy metals and there HM mixture reveal variation in response, where the catalas activity which increase by low concentrations, started to decrease with the higher concentrations (50 $-100 \mu \mathrm{gm} \mathrm{L}-1$ ). As it was illustrated in (Figure 2) both $\mathrm{Cu}$ and $\mathrm{Zn}$ have a more or less the same effect on CAT activity, where except within the high concentration (71- $63 \mathrm{mg} \mathrm{L}-1$ and $74-58 \mathrm{mg} \mathrm{L}-1$ within $100 \mu \mathrm{gL}$ $-1 \mathrm{Cu}$ and $\mathrm{Zn}$ respectively), enhance the CAT activity more than the control (82 - $86 \mathrm{mg} \mathrm{L}-1)$ during the period of the experiment, giving its maximum activity within $10 \mu \mathrm{gm} \mathrm{L}-1$ in case of cupper (110-118 mg L -1 ) and within $5 \mu \mathrm{gm} \mathrm{L}-1$ in case of zinc (116 -120 mg L-1). In contrast to the above, Cd and HM mix. suppressed CAT activity than that recorded in the control throughout the experiment period except within concentration $5 \mu \mathrm{gm} \mathrm{L}-1$ only after $24 \mathrm{~h}$ (85 mg L-1 within Cd and $96 \mathrm{mg} \mathrm{L}-1$ within HM mix.).

\subsection{GR activity}

It is of interest to mention that, in contrast to the above CAT activity, the tree heavy metals support the GR activity within all concentrations and during the entire period of experiment (Figure 3). Nevertheless, GR activity within HM mixture follow the same trend only after 24 hours, meanwhile after $48 \mathrm{~h}$ only the low concentrations enhance GR activity (129 and $139 \mathrm{mgL}-1$ within 5 and $10 \mu \mathrm{gm} \mathrm{L}-1$ respectively), however high concentrations significantly inhibit its activity (65 and $52 \mathrm{mgL}-1$ within 50 and $100 \mu \mathrm{gm} \mathrm{L}-1$ respectively). Except within 10 $\mu \mathrm{gm}$ HM mix. L-1 (77 mg L-1) a more or less the same phenomena were recorded after 96 hours.

\subsection{Up Take of heavy metals}

A glance of table (4) reveal that, the three heavy metals tended to accumulate in the algal cell but with different concentrations during the time of experiment. The tested heavy metals $(\mathrm{Cu}, \mathrm{Cd}$ and $\mathrm{Zn})$ show a significant increase in up take within concentrations. Where, the $\mathrm{Cu}$ concentration in the algal cell fluctuated from $0.05 \mathrm{mg} / \mathrm{g}$ at $5 \mu \mathrm{g} \mathrm{Cu} \mathrm{L-1}$ after $24 \mathrm{~h}$ to $2.6 \mathrm{mg} / \mathrm{g}$ at $100 \mu \mathrm{g} \mathrm{Cu} \mathrm{L}-1$ after $96 \mathrm{~h}$, A more or less phenomena recorded in $\mathrm{Zn}$ up take ranged from $0.07 \mathrm{mg} / \mathrm{g}$ at concentration $5 \mu \mathrm{g} \mathrm{L}-1$ after $24 \mathrm{~h}$ to $3.4 \mathrm{mg} / \mathrm{g}$ at $100 \mu \mathrm{g} \mathrm{L}-1$ after $96 \mathrm{~h}$. It is noticeable that, the rang of uptake in case of Cd $(0.09$ at $5 \mu \mathrm{g} \mathrm{L}-1$ after $24 \mathrm{~h}$ to $4.24 \mathrm{mg} / \mathrm{g}$ at $100 \mu \mathrm{g} \mathrm{L}-1$ after $96 \mathrm{~h}$ ) is significantly higher than that of $\mathrm{Zn}$ and $\mathrm{Cu}$ during the period of experiment $(24,48$ and 96h). Among this, the difference in algal uptake for the three heavy metals within the high concentrations (50 and $100 \mathrm{mgL}-1$ ) were impressive high.

\subsubsection{Canonical corresponding analysis (CCA)}

Overlaying fig (4), by using the Canonical Corresponding Analysis (CCA) the relations between the effect of the three tested heavy metals $(\mathrm{Cu}, \mathrm{Cd}$ and $\mathrm{Zn})$ and its mixture will be more obvious. A high similarity between $\mathrm{Cu}$ and $\mathrm{Zn}$ in their effect on the algal growth which present in the same quarter (side). However, a weaker relation between above effect and that of the HM mixture present in the same side appeared as a dotted line. In contrast to the above, $\mathrm{Cd}$ negatively affected the growth with high dissimilarity, except to certain limit, with the effect of the HM mixture.

\subsubsection{Cluster analysis}

It is of interest to mention that, as shown in cluster analysis (Fig. 4), the effect of the tested heavy metals ( $\mathrm{Cu}, \mathrm{Cd}$ and $\mathrm{Zn}$ ) on the production of both chlorophyll $\mathrm{b}$ and carotenoids were closely related in a minor subgroup. While, chlorophyll a respond differently to the same heavy metals and tended to be highly dissimilar with the other parameters, especially when treated with copper. Regarding (Figure 4) showed that, the algal cell had a more or less the same ability to uptake $\mathrm{Cu}$ and $\mathrm{Zn}$ (high similarity) followed by the ability to up take Cd (with less similarity). Again, concerning the effect of the tested heavy metals on the growth, both copper and zinc tended to relate with each other in minor subgroup. The most noticeable result in (Figure 4) is the high dissimilarity between the effect of the three tested heavy metals on the activity of the two enzymes (CAT and GR) with especial highlight on their dissimilarity between the effect of each heavy metal alone and the mixture of them on the activity of GR enzyme, which related by low similarity with effect of both Cd and HM mixture on CAT enzyme.

\section{DISCUSSION}

\subsection{Inhibition of growth rate}

With significant growth in both urban and industry development, the use of heavy metals has also risen, causing serious environmental problems in water and damage marine life [24,25]. Therefore, assessment of the heavy metals toxicity upon wild microalgae from polluted sites is of exacting importance in ecotoxicology studies, particularly because such wild species are naturally exposed to highly pollution, and consequently transmission transmit heavy metals to the food web. The most commonly used organisms for toxicity tests are the micro- green algae and diatoms, which used as the most standard form, measuring any change in growth rate, so it can survive as integrated environmental monitoring factor [7]. Growth inhibition of microorganism's due to increasing heavy metals concentration in water has been studied in the last two decades [26]. The toxicity of heavy metals depends on both the concentration of heavy metal and the microalgal species, as well as the period of exposure. It is clear from the cited results that, except within low concentration, the inhibition rate of the studied alga (S. obliquus) was increased with increase of the heavy metals ( $\mathrm{Cu}, \mathrm{Cd}, \mathrm{Zn}$ and $\mathrm{HM}$ mix.) concentrations as well as longer exposure period. Concerning exposure of S. obliquus to different $\mathrm{Cd}$ concentrations show that, the growth inhibition was increase gradually and the strong inhibition followed the exposure to the highest levels of $\mathrm{Cd}$, which recorded up to $75.8 \%$ within $100 \mu \mathrm{g} \mathrm{L-1}$ after $96 \mathrm{~h}$ of exposure. There a scientist found that, growth of Scenedesmus obliquus was affected by $\mathrm{Cd}$ concentrations more than $1 \mu \mathrm{g} \mathrm{L}-1$ which directly correlated with the extent of inhibition [27]. One of researcher reported that, growth Tetraselmis chuii was markedly affected by $60 \%$ inhibition when exposed to $50.0 \mu \mathrm{g} \mathrm{L}-1$ of soluble Cd, which agree with the sited results in this study [28]. The decrease in growth rate in Scenedesmus quadricauda after addition of $\mathrm{Cd}$ to its attribution on the respiratory process [29]. On the other hand, the zero effect of the lowest Cd concentration may be deriving from the fact, $\mathrm{Cd}$ is nonessential element for metabolic activities of living organisms [30]. While, the observed growth inhibition in algal cells, within high concentrations of $\mathrm{Cd}$ and $\mathrm{Zn}$, results from interference with basic physiological processes.

Meanwhile, although copper considered as essential micronutrient for algal growth, it takes the second position in toxicity after cadmium (up to $58.9 \%$ growth inhibition after $96 \mathrm{~h}$ ). According to a research, copper toxicity generally due to the presence of free copper ions in the water [31]. This copper ions can influence the permeability, and as a result, the cell loss its potassium ions. At the same time, the result reflected that, $\mathrm{Cu}$ support growth only within the lowest concentration $(5 \mu \mathrm{g} \mathrm{Cu}$ $\mathrm{L}-1)$ as shown in this study. A researcher explain that, presence of $\mathrm{Cu}+2$ in the growth media by low concentration could enhance the peroxidase activity, which involved in indole acetic acid degradation, a hormone widely known by its ability for stimulating growth [32]. On the other side, the presence of low Zn concentration (5 $\mu \mathrm{g} \mathrm{L}-1)$ in the present study enhance the growth (up to $4.1 \%$ ) more than that recorded in the control. In a research, that $\mathrm{Zn}$ promote growth rate, since $\mathrm{Zn}$ is a main metabolic requirement for microalgae where it acts as an important enzyme cofactor [26]. That what explained the mild toxicity of $\mathrm{Zn}$ when compared with $\mathrm{Cd}, \mathrm{Cu}$ and $\mathrm{HM}$ mix. Again, Omar (2002) reported that, low zinc concentrations (i.e. 1.5, 4.5 and $8.0 \mu \mathrm{gL}$ -1) inhibit growth of S. quadricauda. However, higher concentrations support toxicity (20.6 - 37.7\% growth inhibition) as well as longer exposure period. This conclusion is in agreement with suggestion, who reported that, the microalgal cell surface consists of a mosaic of anionic and cationic mutual sites acting as ion exchangers in the medium [33]. So, zinc can affect the microalgal growth during the growth period as agreed by previous researchers [34,35]. Nevertheless, in case of the heavy metal mixture the inhibition was magnified, reflecting the serious problem resulted from discharging different source of pollutants in the aquatic ecosystem.

The present experiment did not study the mechanism of copper toxicity, but pointed out that, copper may affect the permeability of the cell and then disrupting both enzyme activity and cell division, hence reducing the cell growth [36].

4.2 Effects of metals on the photosynthesis 
All the three tested heavy metals and its mix. inhibited the growth of S. obliquus, and the effects were both dose-dependent and timedependent, the toxic order was $\mathrm{HM} \mathrm{mix.>Cd}>\mathrm{Cu}>\mathrm{Zn}$. Unlike the effect on the growth, the impacts on the photosynthesis were more complicated. A researcher also reported that, growth and photosynthesis are independent processes unrelated to each other [37]. Thus, it is necessary to take both growth and photosynthesis into account when estimating the ecological risk of a toxicant, especially under sub-lethal concentrations. Where both zinc and copper enhance the production of chl.a and $\mathrm{b}$ within the low concentration during the exposure period. The result which agree with who reported that, both copper and zinc acts as a micronutrient favouring some physiological activities within low concentrations and then supporting the algal growth [38].

On the whole in spite of some exception (increase of chl.a and b within low concentration of zinc and copper), the higher concentration of $\mathrm{Cu}$ and $\mathrm{Zn}$ beside $\mathrm{Cd}$ and $\mathrm{HM}$ mixture (by all concentrations) reduce caritenoid, chl.a and b. The acute inhibition of photosynthesis related to the role of high concentration of heavy metal which both interrupt the physiological properties of the cell and destruct the chloroplast [39]. In fact, it is well known that $\mathrm{Cd} 2+$ disorganizes chloroplast causing the damage of photosynthetic pigments [40]. High concentrations copper is highly toxic to the algae, affecting both photosynthetic activity and growth. While, $\mathrm{Cu} 2+$ can affect photosynthetic electron transport, oxidize membrane lipids, resulting in an increased quantity of active oxygen, thus affecting photosynthesis of the microalgae. Copper may interfere with mitochondrial electron transport, respiration, ATP production and photosynthesis, causing degradation of carotenoid, chlorophyll a and b. [41].

\subsection{CAT activity}

Generally, concerning enzymatic activity, low concentrations of heavy metals have stimulated CTA activity, while the response is reflected in the case of high concentration (100 $\mu \mathrm{gm} \mathrm{L1})$. This phenomenon can be explained that, small amounts of heavy metals (spatially $\mathrm{Zn}$ and $\mathrm{Cu}$ ) could be used in enzyme synthesis. Stauber and Florence, and also Wilde reported that, the possible mode of zinc and cadmium toxicity are related to the cell membrane, where it may interrupt the uptake of calcium which is necessary for the Ca-ATPase activity during cell division $[41,42]$.

\subsection{GR activity}

Anent GR activity, the recorded results showed that, except HM mixture, the heavy metals support its activity within all concentrations during the entire period of experiment. Previous studies suggested that heavy metals can induce oxidative stress by generating reactive oxygen species (ROS) in aquatic organisms. Indeed, ROS production by exposure to $\mathrm{Cd}, \mathrm{Cu}$, and $\mathrm{Zn}$, mainly superoxide's and peroxides, was detected using fluorophores [43-45]. However, a research reported that, the mechanisms by which heavy metals induces antioxidant responses and to what extent different plant species may share a common defence mechanism are not yet fully understood [46].

\subsection{Up Take of heavy metals}

Microalgae considered as an efficient organism in heavy metal removal from the aquatic environment. They can eliminate metal ions from water in short time by biosorption in uncomplicated systems, without any problems of toxicity. Different microorganisms, have different ability to uptake the same metal, and also, the same microorganisms may be more or less damaged by different metals [47]. Scenedesmus sp has the ability to uptake and accumulate heavy metal in their cells, and known as one of the most efficient microalgae in this process. The data illustrated in table (4) performed that, accumulation of cobalt, zinc and copper by Scenedesmus obliquus increased with increase of the heavy metals $(\mathrm{Cu}, \mathrm{Cd}$ and $\mathrm{Zn})$ concentrations as well as longer exposure period. Where, the uptake of any element from the surrounding media is mostly influenced by the amount present in the water [48]. Also, it can be seen that the tested alga (Scenedesmus obliquus) accumulated an appreciable amount of cadmium more than other that of copper and zinc. However, no significant difference was observed between copper and Zinc. Metal accumulation by Scenedesmus was shown to be in an order of $\mathrm{Cd} 2+>\mathrm{Zn} 2+>\mathrm{Cu} 2+$. This noticeable high rang of uptake in case of Cd (0.09 at $5 \mu \mathrm{g} \mathrm{L}-1$ after $24 \mathrm{~h}$ to $4.24 \mathrm{mg} / \mathrm{g}$ at $100 \mu \mathrm{g} \mathrm{L}-1$ after $96 \mathrm{~h})$ may due to the fact that, cadmium has no known function in cell metabolism at all, so it is solely up taken by adsorption. A research also reported that, Cd toxicity leads to severe disturbances in physiological processes, such as nitrogen fixation, photosynthetic activity and growth [49].
The internally accumulation of cadmium ion in microalgae occurred in two phases of uptake process [50-53]. The first phase is a rapid physicochemical adsorption of cadmium ion onto cell wall binding sites, which followed by period of steady intracellular uptake phase (energy dependent phase).

\section{ACKNOWLEDGEMENT}

This work was funded by the Deanship of Scientific Research (DSR), King AbdulAziz University, Jeddah, KSA under grant No. (130-299D1435). The authors, therefore, acknowledge with thanks DSR technical and financial support.

\section{REFERENCES}

[1] Amundsen, T., Forsgren, E., and Hansen, L. 1997. On the function of female ornaments: male bluethroats prefer colourful females. Proceedings of the Royal Society of London, Series B, 264, 1579-1586.

[2] McKinney J., and Rogers, R. 1992. Metal bioavailability. Environmental Science \& Technology, 26 (7), 1298-1299.

[3] Stephen, E., Ross, I.L., and Hankamer, B. 2013. Expanding the microalgal industry -continuing controversy or compelling case? Current Opinion in Chemical Biology, 17 (3), 444-452.

[4] Nalewajko C. and Prepas E.E. 1996. Responses of phytoplankton photosynthesis and phosphorus kinetics to resuspended sediments in copper sulphate treated ponds. Journal of Environmental Quality, 25 (1), 80-86

[5] Ahluwalia, A.S., and Manjit, K. 1988. Effect of some heavy metal compounds on growth and differentiation in a blue green and a green alga. Microbios, 53, 37-45

[6] Mei, M., Wangzhao, Z., Zijian, W., and Geert, W. 2003. Accumulation, assimilation and growth inhibition of copper on freshwater alga (Scenedesmus subspicatus $86.81 \mathrm{SAG}$ ) in the presence of EDTA and fulvic acid. Aquatic Toxicology, 63 (3), 221-228.

[7] Moreno-Garrido, I, Lubián, L.M., and Soares, A.M.V.M. 2000. Influence of cellular density on determination of EC50 in microalgal growth inhibition tests. Ecotoxicology and Environmental Safety, 47 (2), 112116.

[8] Devriese, M., Tsakaloudi, V., Garbayo, I., Leon, R., Vilchez, R., and Viga, J. 2001. Effect of heavy metals on nitrate assimilation in the eukaryotic microalga Chlamydomonas reinhardtii. Plant Physiology and Biochemistry, 39 (5), 443-448.

[9] Bryan, G.W. 1983. Brown seaweed, Fucus vesiculosus, and the gastropod, Littorina littoralis, as bioindicators of trace metal availability in estuaries. Science of the Total Environment, 28 (1-3), 91-104.

[10] Soderlund, S., Forsberg, A., and Pedersen, M. 1988. Concentration of cadmium and other metals in Fucus vesiculosus and Fontinalis dalecarlica from the northern Baltic Sea and the southern Bothnian Sea. Environmental Pollution, 51 (3), 197-212.

[11] Pena- Castro, J.M., Martínez-Jerónimo, F., Esparza-García, F. and Cañizares-Villanueva, R.O. 2004. Phenotypic plasticity in Scenedesmus incrassatulus (Chlorophyceae) in response to heavy metals stress. Chemosphere, 57 (11), 1629-1636.

[12] Abou-Shanab, R.A.I., Hwang, J.H., Cho, Y., Min, B., and Jeon, B.H. 2011. Characterization of microalgal species isolated from fresh water bodies as a potential source for biodiesel production. Applied Energy, $88(10), 3300-3306$

[13] Omar, H.H. 2002. Bio-removal of zinc ions by Scenedesmus obliquus and Scenedesmus quadricauda and its effect on growth and metabolism. International Biodeterioration \& Biodegradation, 50 (2) 95-100.

[14] Andrews, S., and Sutherland, R.A. 2004. $\mathrm{Cu}, \mathrm{Pb}$ and $\mathrm{Zn}$ contamination in Nuuanu watershed, Oahu, Hawaii. Science of the Total Environment, 324 (1-3), 173-182.

[15] Company, R., Serafim, A., Bebianno, M.J., Cosson, R., Shillito, B., and Fiala-Medioni, A. 2004. Effect of cadmium, copper and mercury on antioxidant enzyme activities and lipid peroxidation in the gills of the hydrothermal vent mussel Bathymodiolus azoricus. Marine Environmental Research, 58 (2-5), 377-381. 
[16] Khallaf, E.A., Galal, M., and Authman, M. 1998. Assessment of heavy metals pollution and their effects on Oreochromis niloticus in aquatic drainage canals. Journal of the Egyptian-German Society of Zoology, 26, 39-74

[17] Rehman, E., Farah, R., and Shakoori, E A. R. 2006. Heavy metal resistant Distigma proteus (Euglenophyta) isolated from industrial effluents and its possible role in bioremediation of contaminated wastewaters Springer Science+Business Media.

[18] Goyer R.A. 1993. Lead toxicity: current concerns. Environmental Health Perspectives, 100, 177-187.

[19] Schlosser, U.G. 1994. SAG-Sammlung von Algenkulturen at the University of Göttingen, Catalogue of Strains 1994. Botanica Acta, 107 (3), 113-186.

[20] Couderchet, M., and Böger, P. 1993. Changes in fatty acid profile induced by herbicides. In: Target Assays for Modern Herbicides and Related Phytotoxic Compounds (P. Böger, G. Sandmann, eds.), Lewis Publ., Boca Raton, FL, USA, pp. 175-181.

[21] Aebi, H. 1984. Catalase in vitro. Methods in Enzymology, 105, 121-130.

[22] Lichtenthaler, H.K., and Wellburn, A.R. 1983. Determinations of total carotenoids and chlorophylls $\mathrm{a}$ and $\mathrm{b}$ of leaf extracts in different solvents. Biochemical Society Transactions, 11 (5), 591592.

[23] Jongman, R. H., Ter Break, C.J., and Van- Tongeren, O.F. 1987. Data analysis in community and landscape ecology. Pudoc, Wageningen: 299p.

[24] Bishop, P. L. 2002. Pollution Prevention: Fundamentals and Practice. Tsinghua University Press, Beijing, 768pp.

[25] Wang, J. L. 2002. Microbial Immobilization Techniques and Water Pollution Control. Science Press, Beijing, 326-332.

[26] Báscik-Remisiewicz, A, Tomaszewska, E., Labuda, K., and Tukaj, Z. 2009. The effect of $\mathrm{Zn}$ and $\mathrm{Mn}$ on the toxicity of $\mathrm{Cd}$ to the green microalga Desmodesmus armatus cultured at ambient and elevated (2\%) CO2 concentrations. Polish Journal of Environmental Studies, 18 (5), 775-780.

[27] Cain, J.R., Paschal, D.C., and Hayden, C.M. 1980. Toxicity and bioaccumulation of cadmium in the colonial green alga Scenedesmus obliquus. Archives of Environmental Contamination and Toxicology, 9 (1), 9-16.

[28] Costa, A.C., and França, F.P. 2003. Cadmium interaction with microalgal cells, cyanobacterial cells, and seaweeds: toxicology and bio- technological potential for wastewater treatment. Marine Biotechnology, 5 (2), 149-156.

[29] Mohammed, M.H., and Markert, B. 2006. Toxicity of heavy metals on Scenedesmus quadricauda (Turp.) de Brébisson in batch cultures. Environmental Science and Pollution Research, 13 (2), 98 -104 .

[30] Tukaj, Z., Báscik-Remisiewicz, A., Skowroński, T., and Tukaj, C. 2007. Cadmium effect on the growth, photosynthesis, ultrastructure and phytochelatin content of green microalga Scenedesmus armatus: a study at low and elevated $\mathrm{CO} 2$ concentration. Environmental and Experimental Botany, 60 (3), 291-299.

[31] Sunda, W.G., and Guillard, R. R. 1976. Relationship between cupric ion activity and the toxicity of copper to phytoplankton. Journal of Marine Research, 34, 511-529.

[32] Wong, P.T.S., Burnison, G. and Chau, Y.K. 1979. Cadmium toxicity to freshwater algae. Bulletin of Environmental Contamination and Toxicology, 23 (4-5), 487- 490.

[33] Davies, A.G. 1974. The growth kinetics of Isochrysisgal- band in cultures containing sublethal concentrations of mercuric chloride. Journal of the Marine Biological Association of the United Kingdom, 54, 157-169.

[34] Shariati M., and Yahyaabadi, S. 2006. The effects of different concentrations of cadmium on the growth rate and beta- carotene synthesis in unicellular green algae Dunaliella salina.

[35] Imani, S., Zarchi, S.R., Hashemi, M., Borna, H, Javid, A, Zand, AM., and Abarghoue, H.B. 2011. $\mathrm{Hg}, \mathrm{Cd}$ and $\mathrm{Pb}$ heavy metal bioremediation by Dunaliella alga. Journal of Medicinal Plants Research, 5(13), 2775-2780.

[36] Stauber, J.L., and Florence, T.M. 1987. Mechanism of toxicity of ionic copper and copper complexes to algae. Marine Biology, 94 (4), 511-519.

[37] Dinesh S., Santhanam, P., Ananth, S., Shenbaga, A., Nandakumar, R., Balaji, B., Jeyanthi, S., Jayalakshmi, T., and Ananthi, P. 2014. Effect of different dosages of zinc on the growth and biomass in five marine microalgae. International Journal of Fisheries and Aquaculture, 6 (1), $1-8$.

[38] Verweij, W., Glazewski, R. and De Haan, H. 1992. Speciation of copper in relation to its bioavailability. Chem. Spec. Bioavail. 4: 43- 51.

[39] Lamaia, C., Kruatrachuea, M., Pokethitiyooka, P., Upat-hamb, E. S., and Soonthornsarathoola, V. 2005. Toxicity and accu-mulation of lead and cadmium in the filamentous green alga Cladophora fracta: A laboratory study. ScienceAsia, 31, 121-127.

[40] Leborans, G. F., and Novillo, A. 1996. Toxicity and bioaccumu-lation of cadmium in Olishodiscus luteus (Raphidophyceae). Water Research, 30, 57-62.

[41] Stauber, J.L., and Florence, T. M. 1990. Mechanism of toxicity of zinc to the marine diatom Nitzschia closterium. Marine Biology, 105 (3), 519-524.

[42] Wilde, K. L., Stauber, J. L., Markich, S. J., Franklin, N. M., and Brown, P. L. 2006. The effect of $\mathrm{pH}$ on the uptake and toxicity of copper and zinc in a tropical freshwater alga (Chlorella sp.). Archives of Environmental Contamination and Toxicology, 51 (2), 174-185.

[43] Pinto, E., Sigaud-Kutner, T.C.S., Leita, O, Okamoto, M.A.S., Morse, O.K., and Colepicolo, D., P. 2003. Heavy metal-induced oxidative stress in algae. Journal of Phycology, 39 (6),1008-1018.

[44] Tzure-Meng, W.U., Yi-Ting, H.S.U., and Tse-Min, L. 2009. Effects of cadmium on the regulation of antioxidant enzyme activity, gene expression, and antioxidant defences in the marine macroalga Ulva fasciata. Botanical Studies, 50, 25- 34.

[45] Okamoto, O.K., and Colepicolo, P. 1998. Response of superoxide dismutase to pollutant metal stress in the marine dinoflagellate Gonyaulax polyedra. Comparative Biochemistry and Physiology, 119 (1), 67-73.

[46] Kim, S., Mi-Young, J., and Young-Mi, L. 2012. Effect of Heavy Metals on the Antioxidant Enzymes in the Marine Ciliate Euplotes crassus. Environmental Risk Assessment and Health Science,1025-1032.

[47] Matsunaga, T., Takeyama, H., Nakao, T., and Yamazawa, A. 1999. Screening of marine microalgae for bioremediation of cadmiumpolluted seawater. Journal of Biotechnology, 70 (1-3), 33 -38.

[48] Fathi, A.A., Zaki, F.T., and Ibraheim, H.A. 2005. Response of tolerant and wild type strains of Chlorella vulgaris to Copper with special references to Copper uptake system. Protistology, 4 (1), 73-78.

[49] Perez-Rama, M., Alonso, J.A., Lopez, C.H., and Vaamonde, E.T. 2002. Cadmium removal by living cells of the marine microalga Tetraselmis suecica. Bioresource Technology, 84 (3), 265-270.

[50] Ter Break, C.J. 1987. CANOCO program for canonical community ordination by Canonical corresponding analysis, principal component analysis and redundancy analysis (version 2.1) TNO Instate of Applied Computer Science, Wageningen, the Netherlands.

[51] Bradford, M.M. 1976. A rapid and sensitive method for the quantitation of microgram quantities of protein utilizing the principle of protein-dye binding. Analytical Biochemistry, 72(1-2), 248-254.

[52] Finney, D. J. 1971. Probit analysis Cambridge University Press, London.

[53] Holm, G. 1954. Chlorophyll mutations in barley. Acta Agriculturae Scandinavica, 4 (1), 457-471. 